\title{
Political branding: sense of identity or identity crisis? An investigation of the transfer potential of the brand identity prism to the UK Conservative Party
}

\section{Christopher Pich \& Dianne Dean}

To cite this article: Christopher Pich \& Dianne Dean (2015) Political branding: sense of identity or identity crisis? An investigation of the transfer potential of the brand identity prism to the UK Conservative Party, Journal of Marketing Management, 31:11-12, 1353-1378, DOI: 10.1080/0267257X.2015.1018307

To link to this article: http://dx.doi.org/10.1080/0267257X.2015.1018307

Published online: 05 Mar 2015.

Submit your article to this journal $\llbracket$

Џll Article views: 205

Q View related articles $\widetilde{ }$

View Crossmark data $\asymp$ 


\title{
Political branding: sense of identity or identity crisis? An investigation of the transfer potential of the brand identity prism to the UK Conservative Party
}

Christopher Pich, Marketing Division, Nottingham Trent University, UK Dianne Dean, Business School, University of Hull, UK

\begin{abstract}
Brands are strategic assets and key to achieving a competitive advantage. Brands can be seen as a heuristic device, encapsulating a series of values that enable the consumer to make quick and efficient choices. More recently, the notion of a political brand and the rhetoric of branding have been widely adopted by many political parties as they seek to differentiate themselves, and this has led to an emerging interest in the idea of the political brand. Therefore, this paper examines the UK Conservative Party brand under David Cameron's leadership and examines the applicability of Kapferer's brand identity prism to political branding. This paper extends and operationalises the brand identity prism into a 'political brand identity network' which identifies the inter-relatedness of the components of the corporate political brand and the candidate political brand. Crucial for practitioners, this model can demonstrate how the brand is presented and communicated to the electorate and serves as a useful mechanism to identify consistency within the corporate and candidate political brands.
\end{abstract}

Keywords political branding; brand identity prism; political marketing; UK Conservative Party; British politics

\section{Introduction}

Brands are strategic assets and key to achieving a competitive advantage (Aaker, 1996), and the concept has been applied to a number of sectors, more recently politics. Brands can be seen as a heuristic device, encapsulating a series of values that enable the consumer to make quick and efficient choices. The notion of a political brand and the rhetoric of branding have been widely adopted by many political parties as they seek to differentiate themselves, and this has led to an emerging interest in the idea of the political brand (French \& Smith, 2010; Pich, Dean, \& Punjaisri, 2014; Smith, 2009a). In addition to the shift in the ideological foundation of political parties (Lane, 1972; Sabatini, 2002), maybe branding could provide a mechanism that aids electoral decision making. However, to suggest that a political brand is like selling cornflakes misjudges nature of the political brand which 
comprises complex inter-related components that are both institutional and ideological but embodied in the personal character of the elected members and the leadership. These inter-related components are dynamic and shaped by the leadership of the political party and also their stakeholders, including the electorate. Therefore, there is an interplay between the internal and the external. This interaction has been conceptualised by Kapferer $(2001,2008)$ as the brand identity prism, but there has been little empirical examination. Therefore, this paper seeks to explore the UK Conservative Party brand under David Cameron's leadership and examine the applicability of Kapferer's brand identity prism to political branding. This is important for political practitioners as they seek to develop a coherent brand that shares consistent values through their policies, leadership and party members.

\section{Brand identity}

The concept of brand identity can be considered a useful approach to generate a deeper understanding of a brand from an internal perspective (Cheng, Hines, \& Grime, 2008; Ross \& Harradine, 2011; Saaksjarvi \& Samiee, 2011; Srivastava, 2011). Brand identity can be conceptualised as the intended projection, formulated and communicated by the brand's creator (de Chernatony, 2006; Joachimsthaler \& Aaker, 1997). Bosch et al. (2006, p. 13) proposed brand identity is the 'aspired associations envisaged' by internal stakeholders. Brand identity conveys what the brand stands for (Van Gelder, 2005) and signifies the reality of the organisation (Nandan, 2005). Moreover, the concept of brand identity focuses on the 'central ideas of a brand and how the brand communicates these ideas to stakeholders' (de Chernatony, 2006, p. 45). However, the notion of brand identity is also complex (Dahlen, Lange, and Smith, 2010; Kapferer, 2008) and a multifaceted construct (Ponnam, 2007; Viot, 2011) with very few frameworks devoted to deconstructing the internal view of a brand.

According to de Chernatony (2006, p. 211), the brand identity prism (Kapferer, 2008) is a 'useful' and 'powerful' conceptualisation of brand identity. For de Chernatony (2006, p. 213), the brand identity prism (Figure 1) not only assesses the competitive differentiation between competing brands 'but also provides an evaluation of the coherence of the brand. For an integrated brand each of the six identity components should reinforce each other'.

According to Azoulay and Kapferer (2003, p. 152), 'the brand identity prism captures the key facets of a brand's identity', and ultimately has the ability to generate a deeper understanding of a brand. Moreover, Kapferer's conceptualisation comprises six dimensions: physique, personality, culture, relationship, reflection and self-image (Dahlen et al., 2010, p. 214; Fill, 2006; Kapferer, 2008). The physique dimension of the prism focuses on the physical, tangible qualities of the brand and goes beyond the brand's logo and colours (Dahlen et al., 2010; de Chernatony, 2006); it includes human qualities of the brand which can be represented by a figurehead/ spokesperson (de Chernatony, 2006; Kapferer, 2001). However, according to Gordon (1999), the personality dimension can also describe the brand's distinctive style of communication. If anything this broadens rather than refines the conceptualisation of personality as personality dimension comprised a more nuanced collection of attributes rather than just the figurehead of a brand.

While the culture dimension of the brand identity prism focuses on the core values and heritage of the brand (Gordon, 1999; Kapferer, 2001), the relationship 
Figure 1 Kapferer's brand identity prism.

Reproduced from de Chernatony (2006) and Kapferer (2008).

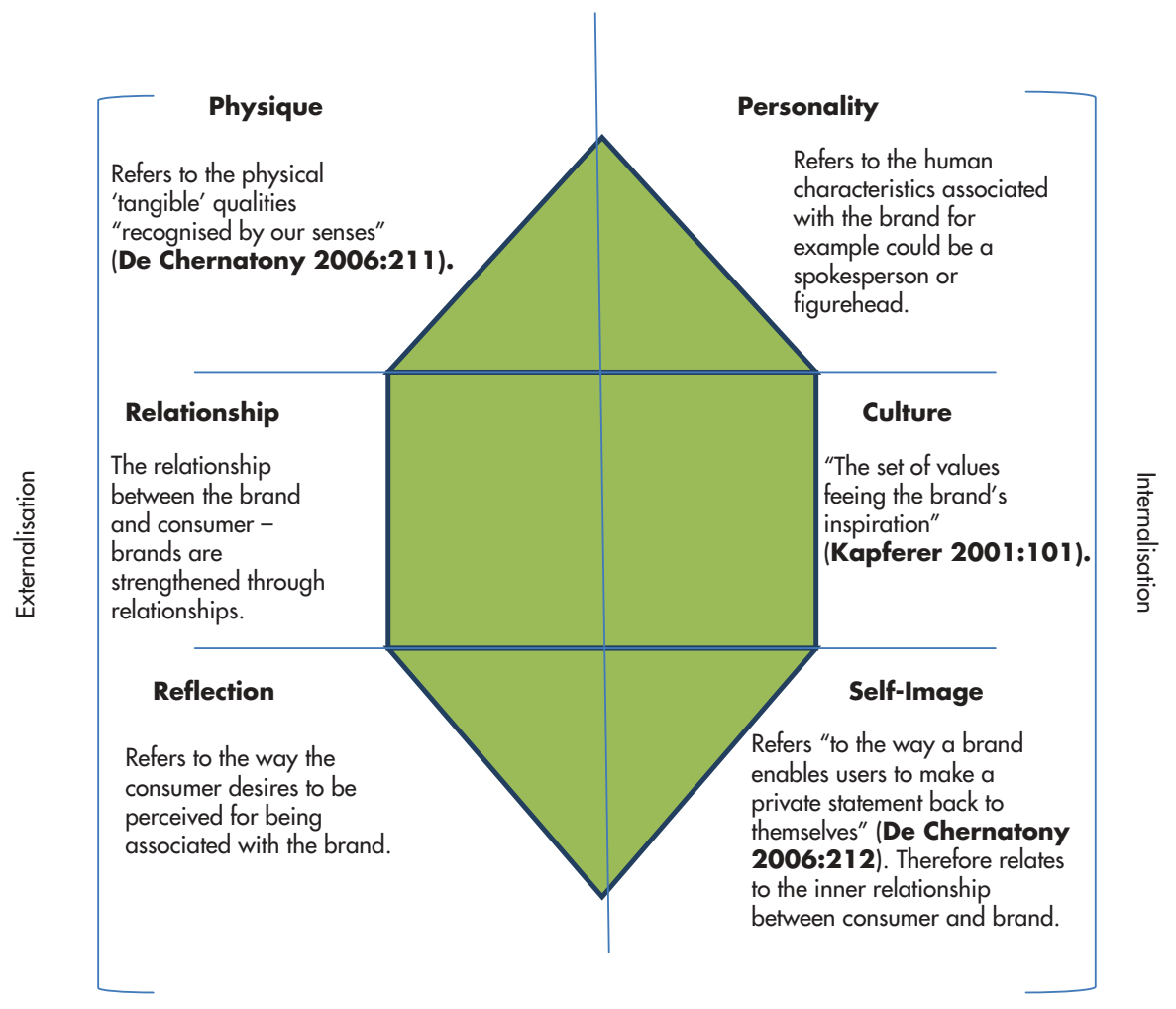

dimension can be surmised as the relationship between the brand and the consumer (de Chernatony, 2006; Kapferer, 2001). However, while de Chernatony (2006) proposed that brands succeed through the relationships formed with consumers, Gordon (1999) further argued that consumers identify humanistic qualities in brands which further strengthens the relationship and thus brand loyalty (Fournier, 1998). Not only is there a relationship between external stakeholders and the brand but to a certain extent internal stakeholders may be considered consumers too, suggesting the relationship dimension may be more complex. However, the relationship between the internal stakeholder and the brand is rarely discussed (de Chernatony, 1999; Harris \& de Chernatony, 2001). The majority of the extant literature that focuses on the brand identity prism fails to acknowledge the complexities of the relationship dimension and the internal relationship between internal stakeholders and brands.

The reflection dimension provides insight into the desired image of the consumer and not necessarily the targeted consumer (Dahlen et al., 2010; Gordon, 1999; Kapferer, 2008), and the self-image dimension relates to the inner relationship between the internal stakeholder and the brand (Kapferer, 2001). For de Chernatony (2006, p. 212), the selfimage dimension refers 'to the way a brand enables users to make a private statement 
back to themselves' and ultimately relates to the inner relationship between the consumer and the brand. Nevertheless, it is the relationship dimension that seems to address the external relationship between the consumer and the brand. Gordon (1999) suggested that brands can be seen as badges that reflect certain characteristics of the individual and the self-image dimension provides insight into the symbolic meaning, personal opinion and beliefs not just about themselves but also how consumers relate to their brands. The self-image dimension along with the culture and personality dimensions forms part of a brand's inward (internal) expressions (Dahlen et al., 2010; Kapferer, 2008). However, when combined with the reflection dimension we may be able to understand how and why the external stakeholder (receiver) builds and conforms with the brand's identity (Kapferer, 2001).

Dahlen et al. (2010) proposed that the physique, relationship and reflection are considered social dimensions that form a brand's outward (external) expression. In contrast, the personality, culture and self-image dimensions form a brand's inward (internal) expression (Dahlen et al., 2010). Kapferer's brand identity prism, therefore, is divided into outward and inward expressions; desired identity; and internal current identity. Additionally, the brand identity prism also includes a vertical division, which can be subdivided into sender (physique and personality) and receiver (reflection and self-image). Kapferer (2008, p. 187) suggested that the relationship and culture dimensions 'bridge the gap between sender and recipient'. Nevertheless, the distinction and divisions within the brand identity prism identify a number of key issues. It is unclear whether the brand identity prism exclusively addresses the concept of 'brand identity' or addresses both 'brand identity' and 'brand image' as the framework refers to external/receiver. Kapferer (2008) makes the distinction between 'sender' and 'receiver' and proposes the receiver refers to the way in which certain 'groups' opposed to 'consumers' decode the signals produced from the brand. Therefore, Kapferer (2008) makes the distinction, yet does not elaborate on this nor acknowledge the conceptualisation of 'brand image' within the brand identity prism. However, it must be remembered that brand identity and brand image are distinct yet related concepts (Dinnie, 2008; Nandan, 2005).

Ultimately, it remains to be seen whether the brand identity prism can be used to examine branding from just an internal perspective or focus on both an internal and external perspective. Given that Kapferer (2008) made the distinction between sender and receiver, internal stakeholders should be considered 'receivers' in the same way as external stakeholders, but there has been scant attention paid to this in the branding literature (Dahlen et al., 2010; de Chernatony, 2007; Harris \& de Chernatony, 2001; Kapferer, 2008, 2001). Both de Chernatony (1999) and Harris and de Chernatony (2001) adapted the brand identity prism from an internal stakeholder perspective and explored the communication gaps between sender (identity) and receiver (reputation). However, there has been little research that illuminates the complexity of the internal-external divisions within the brand identity prism (Azoulay \& Kapferer, 2003; Dahlen et al., 2010; de Chernatony, 2006; Harris \& de Chernatony, 2001).

Finally, the extant literature on the brand identity prism tends to adopt a descriptive illustration of brand identity (Gordon, 1999; Kapferer, 2008; Dahlen et al., 2010), rather than an operational application (see, for instance, de Chernatony, 1999; Harris \& de Chernatony, 2001; Ponnam, 2007; Ross \& Harradine, 2011; Viot, 2011). This indicates that there is further potential to examine the brand 
identity prism exploring the internal orientation of a brand and political branding may serve as a suitable application.

\section{Political branding}

The application of branding concepts and frameworks to the political environment is of growing interest (Baines \& Harris, 2011; French \& Smith, 2010; LeesMarshment, 2009; Lock \& Harris, 1996; Smith \& Speed, 2011). However, despite the interest in this research area there have been only a few studies (Butler, Collins, \& Speed, 2011; Harris \& Lock, 2010; Lilleker, 2005; Peng \& Hackley, 2007; Rawson, 2007; Reeves, de Chernatony, \& Carrigan, 2006; Robinson, 2004).

Branding may be a useful concept to understand political parties as corporate brands and candidates as political brands and there have been calls to investigate the utility of applying branding to politics (Davies \& Mian, 2010; French \& Smith, 2010; Harris \& Lock, 2010; Rawson, 2007; Smith, 2005; Smith \& French, 2009). However, for Baines, Lewis, and Ingham (1999) he was concerned with how to deconstruct the positioning of a political brand. This was explored in part by Pich et al. (2014), who examined the internal stakeholder's perspective of the UK Conservative Party brand during the 2010 UK General Election campaign. While Pich et al. (2014) generated a deeper understanding of the political brand, it did not critically evaluate the process of understanding the political brand. This presents an opportunity to critically assess the mechanisms used to explore the political brand from an internal orientation, and this is currently missing from the extant literature. Furthermore, this may prove beneficial to political actors providing a framework to position the political brand, which could impact on future strategy and communications to external stakeholders (Ormrod, 2011).

In order to address this, future research needs to acknowledge the 'transfer potential from instruments developed for one branding context to others' (Schneider, 2004, p. 60). Extant research highlights that where branding tools, frameworks and scales have been applied to the political environment, they were often modified or extended to suit the unique setting (French \& Smith, 2010; Guzman \& Sierra, 2009; Keller, 1999; Mauser, 1983; Panwar, 2004; Schneider, 2004; Smith, 2009a, 2009b; Smith \& French, 2009). Therefore, future studies that critically apply existing tools or frameworks to the political arena may need to consider this. Hence, there is a case to critically assess the transfer potential of the brand identity prism to the subarea of political branding. This will not only offer a mechanism of how to explore the internal orientation of a political brand but also provide the opportunity to operationalise the brand identity prism.

\section{Political brands: the UK Conservative Party}

This research builds on the work of Pich et al. (2014) and uses the UK Conservative Party brand as the unit of analysis. The UK Conservative Party has been described as a leading UK political brand (Lloyd, 2006) and the oldest political party in the Englishspeaking world (Campbell, 2008). Additionally, the UK Conservative Party has been considered as complex and diverse with frequently contrasting values and interests (Bale, 2008, 2011; Budge, Crewe, McKay, \& Newton, 2001; Coleman, 1988; 
Heffernan, 2001; Hickson, 2005; Kavanagh, 2000; Lee \& Beech, 2009). After three election defeats and three Conservative Party leaders, the UK Conservative Party failed in its attempt to modernise, to reinvent and to reconnect with the electorate (Ashcroft, 2005; Denham \& O’Hara, 2007; Smith, 2009a). In December 2005, David Cameron was elected as leader of the UK Conservative Party, vowing to be different from previous leaders (Campbell, 2008), and arguing it was time to modernise (Denham \& O'Hara, 2007) and unite the Party, making the UK Conservative Party electable again. He attempted to reshape the UK Conservative Party which was, at that time, perceived to be out of touch, focused on immigration and representative of the rich and privileged few (Ashcroft, 2010).

Therefore, this paper seeks to critically assess the applicability of the brand identity prism as a mechanism to explore the UK Conservative Party brand from the perspective of the internal stakeholders. This will generate a deeper understanding of how to operationalise political brand identity and critically evaluate the applicability of the brand identity prism. The following section will set out the research approach including the sampling framework and insight into the analytical process.

\section{Research approach}

According to Creswell (2007) and Graziano and Raulin (2007), the methodological approach is guided and developed based on the research problem and overall aim. Subsequently, as this paper seeks to understand the transfer potential of the brand identity prism as a mechanism to explore the UK Conservative Party brand from the perspective of the internal stakeholders, this paper adopts a qualitative research approach. The aim of qualitative research is to build a comprehensive picture of the respondent's background, attitudes, feelings and experiences from the respondent's own words which go some way in meeting the research problem (Schutt, 2004). Qualitative research is also useful at the early stages of a relatively unknown area (Davies \& Chun, 2002) and can provide the researcher with rich knowledge and unique data which is achieved by delving deep into the respondent's attitudes, feelings, perceptions and beliefs (Covaleski \& Dirsmith, 1990; Malhotra \& Birks, 2003; Rubin \& Rubin, 1995; Warren \& Karner, 2005). The majority of existing research in political branding tends to adopt a measurable, quantitative approach (French \& Smith, 2010), with more exploratory, qualitative research required (Peng \& Hackley, 2007; Smith, 2005). Furthermore, there is a paucity of research that offers in-depth qualitative exploration of a political brand from the perspective of internal stakeholders (Needham, 2006; Pich et al., 2014; Schneider, 2004; Smith \& Speed, 2011). Therefore, as political branding is at the exploratory stage (Lees-Marshment, 2009; Smith, 2009a) a qualitative approach is a suitable standpoint to address the overall aim.

With this in mind, this paper adopted semi-structured, in-depth interviews in order to understand the UK Conservative Party brand from the perspective of internal stakeholders. In-depth interviews often seen as a 'special conversation' (Rubin \& Rubin, 1995, p. 6), can be seen as flexible in terms of topic area development, spontaneous and 'potentially a Pandora's box generating endlessly various and abundant data' (McCracken, 1988, p. 12). Open-ended questions were used as they allow the respondent to lead the interview, with the interviewer simply controlling the interview with the aid of prompts and probes (Foddy, 2001; Gillham, 2005). The 
interview guide/schedule was developed by following a process of 'cyclical development' (Gillham, 2005, p. 22), a visual aid of which is shown in Figure 2.

Figure 2 outlines the process of cyclical development proposed by Gillham (2005) and can be divided into individual steps, which are interrelated. Once the initial interview/focus-group guide has been established, the succeeding steps are trialling, pre-piloting and piloting (Gillham, 2005). Throughout the cyclical process, openended questions/topics were developed, emerged and some were made redundant (Creswell, 2007; Gillham, 2005), resulting in a refined guide ready to conduct the interviews. A copy of the refined interview guide is given in Appendix A.

This paper adopts a purposive sampling approach. Purposive sampling can be considered an appropriate sampling technique as this paper had a specific purpose to explore the UK Conservative Party brand from the perspective of internal Conservative stakeholders (Alston \& Bowles, 2007; Zikmund, 2003). Further to this, a purposive sampling technique is adopted as this paper presents a well-defined sampling criteria of 'internal Conservative stakeholders' ranging all three elements of the UK Conservative Party (Alston \& Bowles, 2007; Daymon \& Holloway, 2011); parliamentary, professionally and voluntary. All three elements of the UK Conservative Party were included in the sampling process as all stakeholders within the organisation build, develop and position the brand (Foster, Punjaisri, \& Cheng, 2010; Harris \& de Chernatony, 2001; Nilson \& Surrey, 1998). A detailed outline of the sample of internal stakeholders who were interviewed as part of this study is given in Appendix B. Sixty internal Conservative stakeholders were contacted via email as part of the recruitment process; however, only half responded to the call for interviews. A sample size of 30 internal Conservative stakeholders were interviewed including Members of the European Parliament (MEP), House of Commons and House of Lords, Councillors, activists, and Prospective Parliamentary Candidates (PPC). Respondents were all active members of the UK Conservative Party. Non-active members were not included in the study as active members were involved in shaping and positioning the UK Conservative Party under the leadership of David Cameron (Ashcroft, 2010; Helm, 2010); hence, active members would provide more insight into the desired and communicated political brand identity. Interviews were conducted prior to the 2010 UK General Election; December 2009-April 2010.

Figure 2 The process of cyclical development. Adapted from Gillham (2005, p. 22).

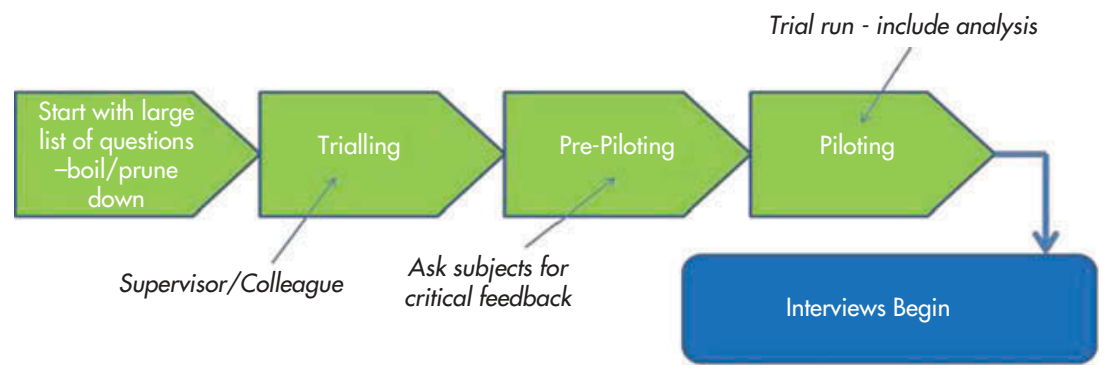


Each interviewee was assured of anonymity to avoid recognition due to the sensitive nature of the study. Each interview was tape recorded, fully transcribed and analysed by the researcher. Drawing on authors such as Butler-Kisber (2010), Kvale (1996), Rubin and Rubin (1995) and Warren and Karner (2005), the transcripts were thematically analysed, looking for patterns and themes. These themes were grouped together in line with the six dimensions of brand identity prism which served as the conceptual framework for this study. This point will be expanded later in the paper. To strengthen the consistency with the interpretive process, each interview/transcript was analysed following the two-stage analytical process outlined by Butler-Kisber (2010, p. 30). This pragmatic process starts with the coarse-grained phase followed by the fine-grained phase and ensures transparency and strengthens validity with the interpretive process (Butler-Kisber, 2010). The following section presents the findings and the critical discussion.

\section{Findings}

The conceptualisation of brand identity served to structure the findings and evaluate the applicability in exploration of the political brand identity of David Cameron's Conservative Party. As stated previously, the brand identity prism is an amalgamation of six identity components including brand physique, brand personality, brand culture, brand relationship, brand reflection and brand self-image (de Chernatony, 2006; Kapferer, 2008). Furthermore, the six components along with the key themes generated from the in-depth semi-structured interviews are shown in Figure 3. This

Figure 3 Key themes from in-depth interviews exploring the brand identity of the UK Conservative Party from the perspective of internal stakeholders applied to Kapferer's brand identity prism.

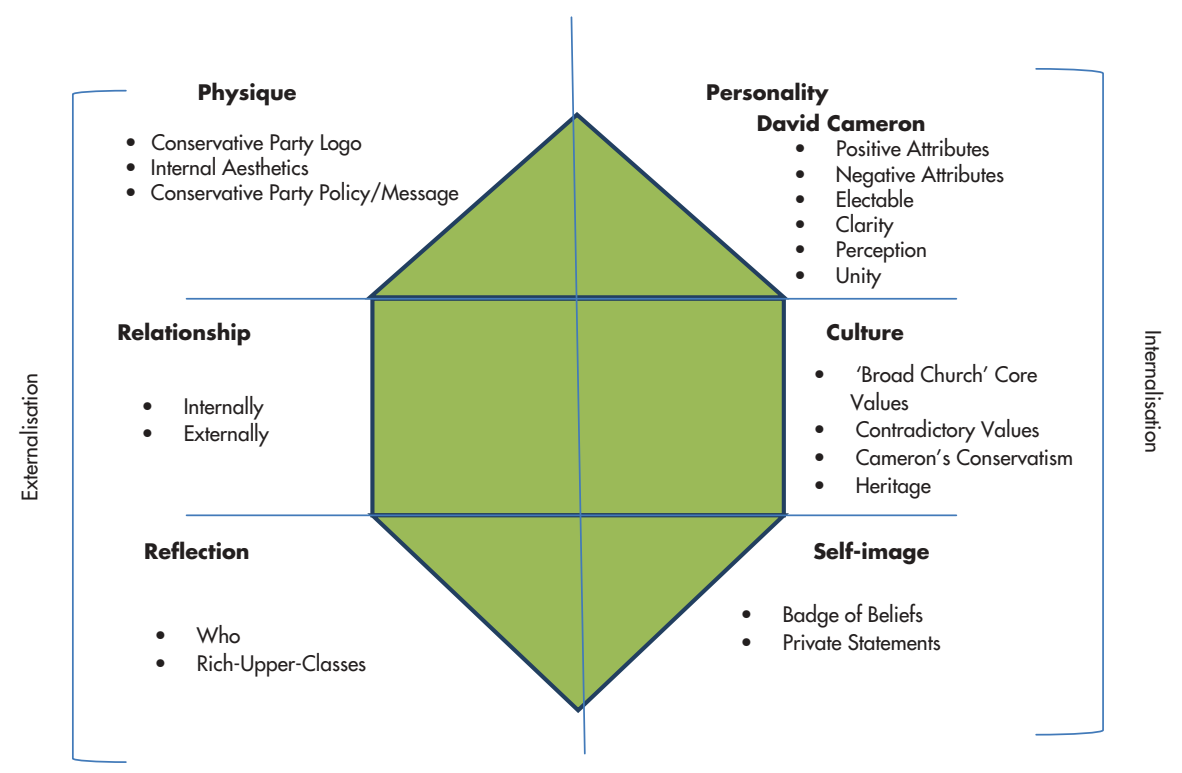


section will also discuss the transfer potential of each dimension and their suitability to the political branding.

This research illustrates that the six dimensions of the brand identity prism can be applied to politics and, in particular, the UK Conservative Party. The model helped to structure the findings but there was a disparity in terms of fit, necessitating adaptation with some of the dimensions including relationship, reflection and self-image. In contrast, physique, culture and personality needed no adjustment.

\section{Physique}

This study demonstrated that the physique dimension could accommodate tangible qualities of the UK Conservative Party brand and go beyond the brand's logo and colours (Dahlen et al., 2010; de Chernatony, 2007; Gordon, 1999; Kapferer, 2008). For example, the findings were subdivided into the UK Conservative Party logo, the physical appearance of the UK Conservative Party (internal aesthetics), and Party policy and message.

The physique dimension also provided a mechanism to understand the consistency of the tangible elements of the political brand. For example, it was also found that the UK Conservative Party did not portray a clear brand message, highlighting a series of inconsistencies and tensions within the physique dimension. More specifically, internal Conservative stakeholders provided varied responses to the UK Conservative Party replacing the flaming red/blue 'torch' logo with the new 'oak tree' logo, after David Cameron's leadership victory in 2005. These ranged from positive responses and negative responses, to the non-adoption or usage of the 'oak tree' logo. A Conservative councillor from Lincolnshire and also the campaign manager for a 2010 (PPC) argued:

I thought the torch was more strident ... represented Margaret Thatcher ... Britain in the world going forward. The tree is an eco; we jumped on the ecogreen-bandwagon vote blue go green I don't agree with it. So the tree logo in my opinion is a very nice green logo but it's not exactly strong ... it doesn't say anything about us. (P4)

Additionally, several internal stakeholders emphasised local, personalised and 'established' (P1) political brands, which were often detached from the corporate or national UK Conservative Party brand. This was emphasised by a Conservative councillor from Yorkshire:

Apart from it [sic] goes on the ballot papers, I have completely ignored it. Why? I dislike it, I don't understand it. I created my own brand ... I founded it back in 1983 when I was first elected ... and I am not going to throw away a recognised brand ... we make the brands in the provinces. (P1)

Therefore, this research highlighted significant applicability of the tangible elements of the UK Conservative Party to the physique dimension of the brand identity prism. Thus, the physique dimension required no adaptation as the findings were consistent with the definition set out in the original conceptualisation (Dahlen et al., 2010; de Chernatony, 2007; Gordon, 1999; Kapferer, 2008). 


\section{Personality}

This research demonstrated that themes related to the political brand's figure head can be applied to the personality dimension of the brand identity prism, however, with some adaptation. The conceptualisation of the personality dimension required greater focus to enhance the dimension's transfer potential to political branding. For example, as Kapferer (2008) argued that the personality dimension could equate to the figurehead or spokesperson of a brand; in the context of this paper, David Cameron is the current leader and figurehead of the UK Conservative Party. Therefore, findings relating to David Cameron were accommodated in this dimension. The findings were thematically coded into positive attributes, negative attributes, electable, clarity, perception and unity. For example, David Cameron was also regarded as a 'strong determined fellow, done things that were needed' (P24), 'has a genuine broad appeal ... bold ... wise' (P13), the 'very image of the modern Conservative Party' (P8), 'caring ... young ... dynamic ... trusting ... supporter of the NHS' (P2) and 'positive ... competent ... charismatic ... charming' (P1). Example of the negative attributes ranged from personal characteristics, perceived values and ideology and David Cameron's style of communicate. According to a professional member of the UK Conservative Party, 'there's no ideology and I'm a bit worried that Cameron doesn' t believe in ideology ... don't know enough about him ... just a bit more substance' (P15). One senior Conservative MP argued, 'in all the expenses business ... he's [Cameron] been hunting with the pack ... I know colleagues hauled out and publically guillotined on the basis of an accusation rather than a proven charge ... he's been really ruthless' rather than 'have a duty of care' and supporting parliamentary colleagues in the Conservative Party (P10).

The personality dimension also highlighted some overlap with some of the themes relating to David Cameron. For example, David Cameron's emphasis of Conservatism could have been included in the personality dimension as this related to the figurehead of the brand. However, his emphasis of Conservatism could also be included in the culture dimension as this related to the current emphasis or perspective of the UK Conservative Party. This highlights the complex relationship within political brands between the party leader, their political position and the culture of the political party. Therefore, it was more appropriate to include David Cameron's emphasis of Conservatism in the culture dimension as this was consistent with Kapferer's (2008) original framework. This point is expanded in the culture dimension.

The findings also proposed that the personality dimension could be further subdivided into individual candidates or politicians as each entity can be considered a figurehead of their own 'individual political brand'. For example, one Conservative Member of Parliament argued:

I campaign very much on broadly local issues and on the reputation of being independent minded ... in politics what matters is your reputation and you have to establish that from day one. (P10)

de Chernatony (1999) and Harris and de Chernatony (2001) argued that brand personality traits are developed through associations with not only the brand's figurehead but also internal stakeholders. This strengthens the argument for the exploration of the personality dimension on an individual level and highlights the multifaceted nature of the personality dimension in political branding. This was also 
reinforced by a member of the professional element of the party who argued the Conservative Party has

overemphasised the DC [David Cameron] brand and not worked enough on the Conservative brand ... worked hard on the physical process of rebranding but not enough on the message ... not clear enough ... what do they stand for. (P15)

This also suggests that the brand identity of individual candidates and politicians can be explored using the brand identity prism. Further, this reinforces the idea that political brands can be seen as a collection of individual sub-brands unified under the banner of the corporate political brand (de Chernatony, 1999; Harris \& de Chernatony, 2001). Ultimately, the findings relating to the UK Conservative Party figurehead, David Cameron, were easily applied to the personality dimension of the brand identity prism but with some adaptation. Furthermore, this paper illustrates that the personality dimension can equate to the figurehead of individual political brands such as candidates and politicians. This study also highlighted the multifaceted nature of the personality dimension. Therefore, this paper operationalises the personality dimension to enable application to political parties and candidates.

\section{Culture}

This study demonstrated that the culture dimension can accommodate core values and themes relating to the heritage of the UK Conservative Party (Gordon, 1999; Kapferer, 2001). More specifically, these themes included the idea that the UK Conservative Party is considered a 'broad church', possesses contradictory core Conservative values, David Cameron's emphasis of Conservatism and the heritage of the UK Conservative Party. For example, the majority of internal stakeholders promoted a consistent, non-contradictory approach when revealing the core values of the UK Conservative Party. Participants proposed that the UK Conservative Party may be considered a 'broad church' (P13), or 'coalition' (P28) of diverse and unique strands and perspectives united by core principles such as freedom and the individual. For example, a Conservative Member of Parliament argued:

It is a broad church and I think there are some uniting defining features in the Conservatives whether they are pro-Europe or much more libertarian in their outlook there's a round view that we support an individual ... and bigger individual society within a bigger state ... but there are broad themes that I think unite all those within the parliamentary party and the party at large. (P27)

Similarly, one Conservative councillor said, 'Conservative identity differs from Conservative to Conservative and depends on what the Conservative believes' (P1), and 'one can still harbour personal values but united in the core values' (P3). Along with eternal core values, tolerance and respect were seen as Conservative traits that unite the party in this broad church. 'We all coexist together and can live with division and different points of view. A country with sixty million people you're going to have different views ... coexist with eternal values ... tolerance is a strong Tory trait', expressed by a Conservative MEP (P21).

However, internal stakeholders often presented core Conservative values (Budge et al., 2001; Hickson, 2005; Kavanagh, 2000; Norton, 1996) as personal Conservative values and vice versa, and it was often difficult to distinguish between the two. This highlights the complexity of political brands. Nonetheless, the 
conceptualisation outlined by Kapferer (2008) does not evaluate the cultural values of individual stakeholders (individual brands) or make a distinction between cultural values of the (corporate) brand and internal stakeholders (individual brand). Kapferer's (2008) conceptualisation merely focuses on the cultural values and heritage of the corporate or national brand. Nevertheless, Harris and de Chernatony (2006) make reference to this distinction; however, they provide little depth and discussion on this key point. Perhaps the 'self-image dimension' that refers to the inner-relationship between the internal stakeholder and the UK Conservative Party brand may be seen as more appropriate to accommodate 'personal core values' of individual candidate brand identity. Again, this highlights the overlapping nature of the brand identity model and the application of the dimensions will be dependent on the nature of the research.

Subsequently, this idea of a 'broad church' UK Conservative Party can be seen as something of a paradox; a coalition of often conflicting subcultures, each unique to the individual, nevertheless, united by core yet broad principles of the UK Conservative Party organisation. This paper highlights the significant transfer potential of the culture dimension in exploration of political brand identity.

\section{Relationship}

The application of the relationship dimension was more difficult in its original conceptualisation. Most notably it fails to acknowledge the complexities of the relationship dimension and the internal relationship between internal stakeholders and brands. This paper adapted the relationship dimension to accommodate the findings related to the internal-Conservative Party brand relationship and the internal stakeholder's interpretation of the relationship between the electorate and the UK Conservative Party. The findings were thematically categorised into 'internal' relationships and 'external' relationships.

For example, the relationship dimension highlighted that the relationship between the Conservative Party and the internal stakeholders requires some attention. Despite many internal stakeholders consistently revealing a 'distinct' decentralised relationship between the internal stakeholders and the UK Conservative Party brand, consistent with the 'broad church' approach expressed in the culture dimension, this was undermined by several participants expressing tension, disconnect and resentment. According to one Prospective County Councillor, Parliamentary Aide to a former Minister of State, 'he's [Cameron] not running the party internally very well ... [Including] candidate selection ... this is pissing off loads of members. [Members] they' re just sceptical and hostile towards them [Conservative Campaign Head Quarters [CCHQ]' (P25). Furthermore, 'it's more of an organisational thing, the message is right I' $\mathrm{m}$ convinced of that but the gaffs have been allowed to happen ... CCHQ getting it wrong sometimes and I am worried' (P25). This contention was found at various levels of the UK Conservative Party including prospective parliamentary candidates, MEP, members of subgroups allied to the party and a member of the House of Lords. Furthermore, this contention was often downplayed by internal stakeholders that felt it was not the 'right time' to voice their concerns so close to a General Election and the Conservative Party had to appear united and harmonised in order to win.

The relationship dimension also highlighted that internal stakeholders also envisaged a 'decentralised relationship' between the Conservative Party and the 
external members (citizens), consistent with one of their key cultural values; decentralisation. A 'decentralised relationship' equated to returning power to the individual and less state intervention. Despite this, the findings suggested that there was an element of uncertainty and doubt whether the UK Conservative Party brand was resonating with and convincing the electorate especially outside the London area. One Conservative London Assembly Minister argued:

I think he [Cameron] has a greater appeal to the closer to London you are ... But I think not as yet as good the further you go from London ... I think people in London and the outer area understand his agenda ... I think possibly it hasn't resonated quite as well in some of the other heartlands. (P8)

Therefore, in part it was believed that there was no 'reciprocal relationship' between the UK Conservative Party brand and the electorate which could be shaped by internal stakeholders. Some of the internal stakeholders failed to accept that they have a role to play in building a relationship between the UK Conservative Party brand and the electorate (Harris \& de Chernatony, 2001; Nilson \& Surrey, 1998). It was also argued that there are different kinds of relationships; some more difficult than others, at different levels of the Conservative Party between the Conservative Party and the electorate depending on the electoral voting system. For instance, the UK General Election is 'first past the post' and the European elections are determined by proportional representation. This was emphasised by a Conservative MEP that stated it is 'very, very difficult' for MEP to relate and connect with the electorate, the same way Members of the Westminster Parliament and councillors relate to the electorate (P17). Political representatives elected via the first-past-the-post voting system were 'very much more in touch with people on the ground' (P17). The Conservative MEP continued, 'it's very difficult to do that under this system' of proportional representation and constituents under this system may run into millions opposed to thousands (P17). Therefore, the electoral voting system can affect the relationship between the political brand and the electorate in terms of development, communication strategy and relevance and is another element to consider along with internal stakeholders in the relationship dimension.

Accordingly, it can be argued that the relationship dimension is complex and can be approached from an internal brand perspective (de Chernatony, 1999; Harris \& de Chernatony, 2001) and also the perceived external brand perspective (Kapferer, 2008). This was also consistent with the definition of internal brand identity. In addition, it is proposed that there are multiple relationships connected to the UK Conservative Party brand. The findings could only be applied to the relationship dimension once it had been reframed and operationalised.

\section{Reflection}

The reflection dimension focused on the expected or envisaged supporter of the UK Conservative Party brand from the perspective of internal stakeholders and not the target market. Dahlen et al. (2010, p. 215) argued, 'the brand should be a reflection of who consumers would like to be not who they actually are', suggesting the reflection is envisaged and not necessarily reality. Kapferer (2008, p. 186) proposed that the terms 'reflection' and 'targeting' are often confused; however, all brands must control their reflection and recognise the difference between targeting. Future reflection dimensions within the brand identity prism could include the 'reflection' 
and 'targeting' distinction to avoid confusion, provide clarity and highlight contradictions/consistencies between the two concepts.

In the context of this paper, the reflection dimension accommodated themes such as 'who' the UK Conservative Party was considered to represent and 'perceptions' relating to social class. The majority of internal stakeholders revealed a consistent reflection in that the UK Conservative Party was not designed to appeal to a defined segment of society. For example, one Conservative Peer argued that the Conservative Party is a 'national party ... it's got to transcend all classes' (P6), with similar views outlined by a Conservative MP, the party 'has to appeal right across society' (P11), to 'all people from diverse backgrounds' (P24). However, this inclusive proposition with something to offer everyone was undermined by the 2010 General Election targeting strategy employed by the UK Conservative Party (Ashcroft, 2010), by several internal stakeholders including Conservative MPs and MEPs and contradicted by appealing to the middle ground on the ideological continuum (Beech \& Lee, 2008).

Opinion on social class and its relationship with the UK Conservative Party was another contrasting theme. It was argued that the UK Conservative Party no longer wholly represented the rich and privileged in society. One Conservative MP argued:

There's always this. I'm from Doncaster I know exactly what the perceptions are of the Conservative Party particularly in dominant Labour areas that feel it's a party only interested in rich people and big business ... and I wouldn't be in it if that's what I thought ... I certainly don't have that heritage. (P14)

While it was also proposed that it was the perception that the party cared most about the privileged few still remained, in contrast to one Conservative MEP, who argued that the Party-of-the-rich associations were not necessarily negative. For example, the MEP believed it:

Depends on where you go. I still meet people who say 'I'm voting for you because you're the party of the rich' and a lot of people say 'I couldn't vote for you people because you only look after your own'. (P18)

Consequently, this paper demonstrates that the idea of the political brand from the perspective of internal stakeholders can be applied to the reflection dimension of the brand identity prism. The relationship between the reflection, relationship and physique dimensions, all social, outward facing dimensions (Dahlen et al., 2010; Kapferer, 2008), are discussed following the self-image dimension application and applicability discussion.

\section{Self-image}

The self-image dimension was also complicated, partly due to the lack of clarity with the conceptualisation of self-image. Keeping in mind brand identity is on the sender's side' (Kapferer, 2001, p. 94) with envisaged associations (Bosch et al., 2006) and defining the organisation's reality (Nandan, 2005), it can be proposed that brand identity is the desired identity of a brand developed and promoted by internal stakeholders. Therefore, the self-image dimension in this study referred to the inner relationship (Kapferer, 2001) between the internal stakeholder and the UK Conservative Party brand, consistent with the definition of internal brand identity.

Once the conceptualisation of the self-image dimension had been clarified, the findings were transferred to the brand identity prism. The findings were broadly 
themed 'badge of beliefs' and 'private statements'. 'Badge of beliefs', due to the findings, reflected certain characteristics of the individual, such as personal narratives and biographical information. For example, a Conservative MP claimed to come from a working-class background, became an MP by 'default', starting life as a 'humble' farm worker and progressing to become a local councillor. Claiming to be more 'right-wing than Cameron', he believed in rewarding people who play by the rules and work hard, and supporter of localism (P11).

The findings were also categorised 'private statements' since the findings referred to personal opinion, feelings and symbolic meaning relating to the UK Conservative Party brand. One Conservative MP revealed:

To me the message is fairly clear. Namely we need to change course, we've been too state orientated, too target oriented, insufficient encouragement of initiatives for individuals, companies, organisations, public sector organisations ... but I think that the problem is we [the party] haven't put that quite across sort of what's the alternative ... I'm sure the Conservative Party's not short of ideas but finds it difficult to get those ideas across [sic] so I don't think people yet bought into that Cameron is right I think they think Cameron maybe. (P26)

All internal stakeholders revealed personal accounts, unique biographical information and private narratives of how they became members of the UK Conservative Party. For example, one Conservative MEP stated:

I do think we are losing meritocracy in our party through the way our MEP selection for example, where vacancies go to women [sic] not meritocratic ... now there are a lot of people who think that you should get a seat because they're from unrepresented groups and I think that's a bit worrying ... [central Conservative Party] their idea of a black candidate is an African Etonian or Asian candidate is an Asian millionaire ... I want us to be back to the party of aspiration. (P19)

Therefore, the findings suggested that there are 'multiple brand identities' within the UK Conservative Party connected by 'broad church' core values consistent with the values revealed in the culture dimension. These multiple brand identities serve as a basis for a 'community of thought' (Kapferer, 2008, p. 187) which enables users of the brand to form relationships with other users yet retain their own personal badge of beliefs (de Chernatony, 2006; Gordon, 1999; Kapferer, 2001).

However, the findings under the 'badge of beliefs' and 'private statements' categories reflected the personal opinion, beliefs and attitudes of individual participants and could have been applied in various dimensions including physique, personality and/or culture. For example, 'private statements' about David Cameron could have been placed in the 'personality' dimension as these themes related to the figurehead. Similarly, 'private statements' regarding the 'heritage' or 'values' of the party could have been placed in the 'culture' dimension as this would have been consistent with the dimension's definition. However, these 'private statements' and 'badge of beliefs' were placed in the 'self-image' dimension as they provided insight into the inner relationship between the internal stakeholder and the UK Conservative Party brand. Therefore, this strengthened the idea of the interchangeability of the brand identity prism dimensions. 


\section{Discussion}

This paper highlighted the problematic nature of applying the brand identity prism in its original form to explore the internal orientation of a political brand. More specifically, a political brand can be applied to the brand identity prism; however, a number of dimensions of the prism had to be adapted (relationship, reflection, selfimage) and required greater consideration in terms of applicability. While there was little or no difficulty in applying the findings to the physique, culture and personality dimensions.

This research also highlighted the complexity of exploring a political brand through Kapferer's original conceptualisation. Hence, political brands are potentially a collection or a 'broad church' of individual political brands united under the umbrella or corporate/national brand otherwise known as the political party. The collection of individual political brands is encouraged to unify under the corporate political brand by the party leader and the party leader's emphasis, ideology, party policy and positioning. This paper therefore presents the 'political brand identity network'; a model designed to deconstruct the internal identity of corporate and individual political brands. The 'political brand identity network' is shown in Figure 4 and summarised in Table 1.

Table 1 provides an operationalisation of the political brand identity network. Furthermore, Figure 4 presents a framework to deconstruct internal brand identity and that can be used to explore several dimensions of a political brand. For example, the framework can be adopted to understand the internal identity of a corporate political brand (in this case, the UK Conservative Party). The framework can also be used to explore individual/sub-brands of candidates and politicians. The six

Figure 4 The political brand identity network - developed from the original brand identity prism and its application to political branding.

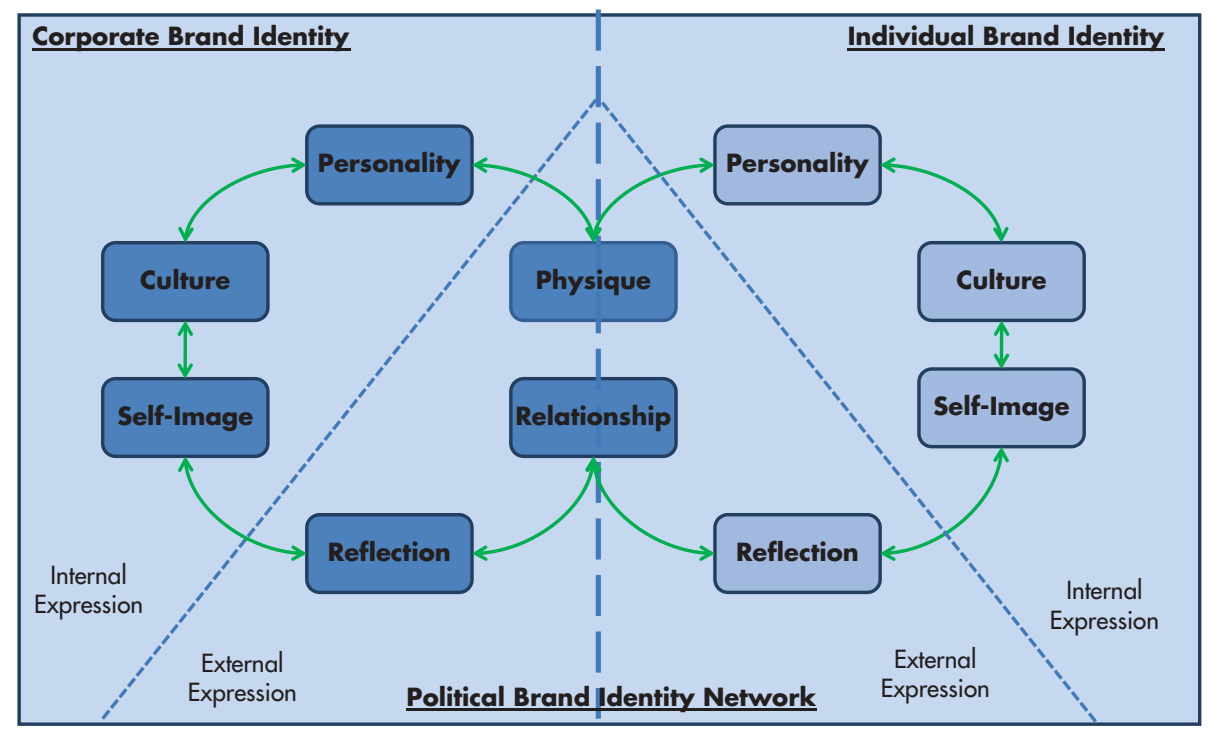




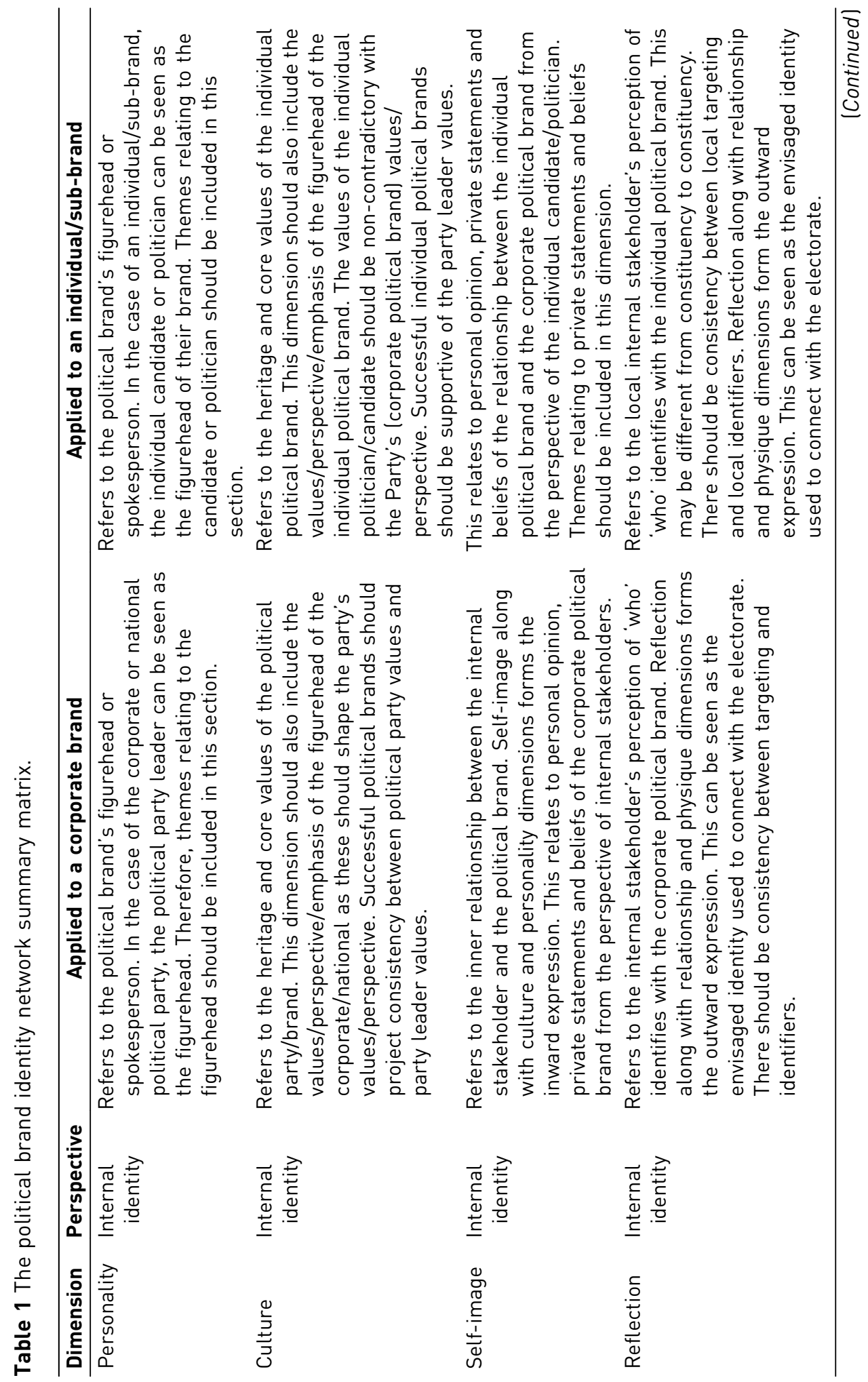




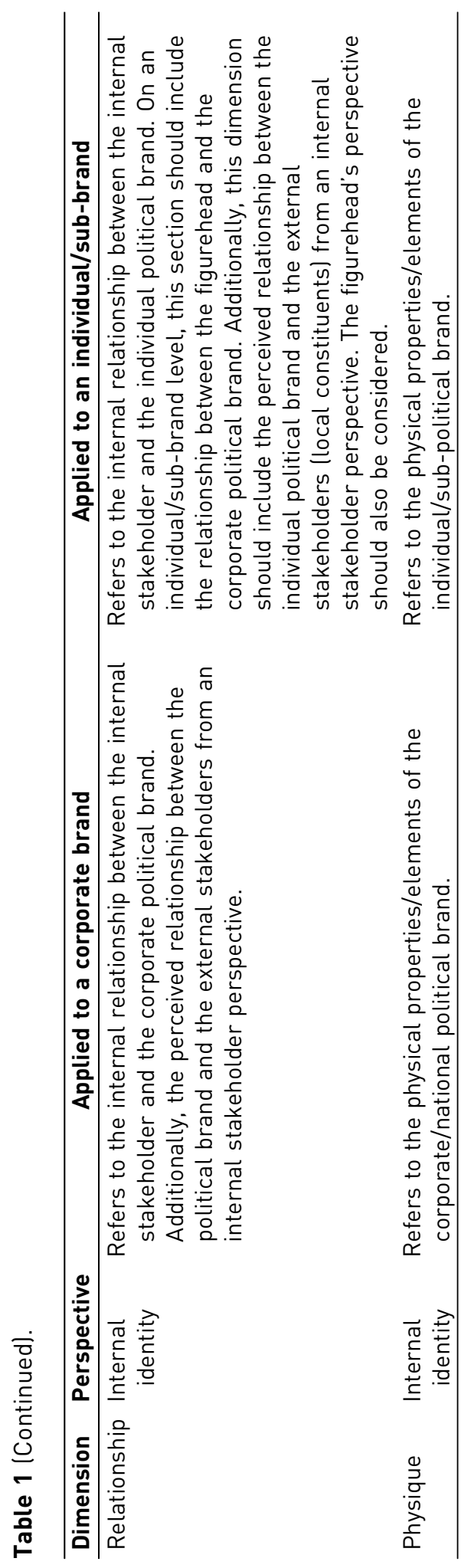


dimensions of brand identity are tailored (Table 1) to address the unique nature of political brands and will be dependent upon the focus of the research.. For example, a study that focuses on a corporate brand would consider the operationalisation and conceptualisation on the left side of the framework (Figure 4). If a study focused on an individual political brand (candidate/politician), it would consider the right side of the framework and column (Table 1). The political brand identity network can also be used to understand the relationship between a corporate political brand and an individual (candidate/politician) political brand. The similar dimensions enable a pragmatic approach to evaluate the consistency between the distinct political brands (de Chernatony, 2006; Gordon, 1999; Kapferer, 2001). The 'political brand identity network' can be used exclusively to explore the internal orientation of a brand. This is consistent with brand identity (Dahlen et al., 2010 Kapferer, 2008; Ponnam, 2007; Viot, 2011) and clarifies the distinction with external brand image (Nandan, 2005; Wong, 2010).

\section{Conclusion}

This paper demonstrated the significant transfer potential of the six dimensions of identity in exploration of a political brand from an internal orientation. The political brand identity network generated a deeper understanding of the UK Conservative Party brand identity prior to the 2010 UK General Election. Moreover, this paper provides a critical assessment of an established concept to a new application and offers an operational approach to explore the multidimensional nature of political brands using the 'the political brand identity network'. This is in contrast to the descriptive illustrations of the brand identity prism (de Chernatony, 1999; Harris \& de Chernatony, 2001; Ponnam, 2007; Ross \& Harradine, 2011; Viot, 2011).

Accordingly, this paper also makes a managerial contribution to knowledge. The applied brand identity prism can be used by political parties, politicians and candidates to understand the way in which the brand is presented and communicated to the electorate and serves as a useful mechanism to identify consistency within the corporate and personal political brands. Furthermore, this paper goes some way in addressing calls for more research in the subdiscipline of political marketing (Baines \& Harris, 2011; Harris \& Lock, 2010; LeesMarshment, 2009; Lilleker, Jackson, \& Scullion, 2006; Moufahim \& Lim, 2009; O'Shaughnessy \& Henneberg, 2007; Osuagwu, 2008), particularly the application of strategic management to a political setting (Baines \& Harris, 2011).

It may be advantageous to build on this paper and generate a deeper understanding of the UK Conservative Party brand from an external brand image perspective. Exploring the UK Conservative Party brand image will provide more of a complete picture of the political brand and ascertain whether the internally created and communicated message is understood externally in the mind of the electorate. Furthermore, considering the external brand image along with the internal brand identity will also highlight whether there are communication gaps between the two distinct yet related concepts. Finally, future research could consider the transfer potential of the brand identity prism to other subdisciplines of marketing and assess the applicability to different contexts. 


\section{References}

Aaker, D. (1996). Building strong brands. London: Simon \& Schuster.

Alston, M., \& Bowles, W. (2007). Research for social workers: An introduction to methods. London: Routledge.

Ashcroft, M. A. (2005). Smell the coffee: A wake-up call for the Conservative Party. CGI Europe.

Ashcroft, M. A. (2010). Minority verdict: The Conservative Party, the voters and the 2010 election. London: Biteback.

Azoulay, A., \& Kapferer, J. (2003). Do brand personality scales really measure brand personality? Journal of Brand Management, 11(2), 143-155. doi:10.1057/palgrave. bm.2540162

Baines, P., \& Harris, P. (2011). Marketing in the 2010 British General Election: Perspectives, prospect and practice. Journal of Marketing Management, 27(7-8), 647-655. doi:10.1080/ 0267257X.2011.591916

Baines, P. R., Lewis, B. R., \& Ingham, B. (1999). Exploring the positioning process in political campaigning. Journal of Communication Management, 3(4), 325-336. doi:10.1108/ eb023496

Bale, T. (2008). A bit less bunny-hugging and a bit more bunny-boiling? Qualifying Conservative Party change under David Cameron. British Politics, 3(3), 270-299. doi:10.1057/bp.2008.7

Bale, T. (2011). The Conservative Party from Thatcher to Cameron. Cambridge: Polity Press.

Beech, M., \& Lee, S. (2008). Ten years of new labour. Basingstoke: Palgrave Macmillan.

Bosch, J., Venter, E., Han, Y., \& Boshoff, C. (2006). The impact of brand identity on the perceived brand image of a merged higher education institution: Part one. Management Dynamics, 15(2), 10-30.

Budge, I., Crewe, I., McKay, D., \& Newton, K. (2001). The new British politics. Harlow: Pearson.

Butler, P., Collins, N., \& Speed, R. (2011). The Europeanisation of the British political marketplace. Journal of Marketing Management, 27(7-8), 675-690. doi:10.1080/ 0267257X.2011.593540

Butler-Kisber, L. (2010). Qualitative inquiry: Thematic, narrative and arts-informed perspectives. London: Sage.

Campbell, J. (2008). In defence of David Cameron: How the Tories have gotten past soul searching in opposition. Review - Institute of Public Affairs, 60(1), 33-36. Retrieved from http://www.ipa.org.au/library/publication/1210833688_document_60-1_campbell.pdf

Cheng, R., Hines, T., \& Grime, I. (2008). Desired and perceived identities of fashion retailers. European Journal of Marketing, 42(5/6), 682-701. doi:10.1108/03090560810862589

Coleman, B. (1988). Conservatism and the Conservative Party in nineteenth century Britain. London: Hodder \& Stoughton.

Covaleski, M., \& Dirsmith, M. (1990). Dialectic tension, double reflexivity and the everyday accounting researcher: On using qualitative methods. Accounting, Organizations and Society, 15(6), 543-573. doi:10.1016/0361-3682(90)90034-R

Creswell, J. W. (2007). Qualitative inquiry and research design. London: Sage.

Dahlen, M., Lange, F., \& Smith, T. (2010). Marketing communications: A brand narrative approach. West Sussex: John Wiley and Sons.

Davies, G., \& Chun, R. (2002). Gaps between the internal and external perceptions of the corporate brand. Corporate Reputation Review, 5(2/3), 144-158. doi:10.1057/palgrave. crr.1540171

Davies, G., \& Mian, T. (2010). The reputation of the party leader and of the party being led. European Journal of Marketing, 44(3/4), 331-350. doi:10.1108/03090561011020453

Daymon, D., \& Holloway, I. (2011). Qualitative research methods in public relations and marketing communications. New York, NY: Routledge. 
de Chernatony, L. (1999). Brand management through narrowing the gap between brand identity and brand reputation. Journal of Marketing Management, 15(1/3), 157-179. doi:10.1362/026725799784870432

de Chernatony, L. (2006). From brand vision to brand evaluation (4th ed.). Oxford: Butterworth-Heinemann.

de Chernatony, L. (2007). From brand vision to brand evaluation. Oxford: ButterworthHeinemann.

Denham, A., \& O'Hara, K. (2007). The three 'Mantras': 'Modernisation' and the Conservative Party 1945-2005. British Politics, 2, 167-190. doi:10.1057/palgrave.bp.4200057

Dinnie, K. (2008). Nation branding: Concepts, issues, practice. Oxford: ButterworthHeinemann.

Fill, C. (2006). Marketing communications. Essex: Pearson Education.

Foddy, W. (2001). Constructing questions for interviews and questionnaires: Theory and practice in social research. Cambridge: Cambridge University Press.

Foster, C., Punjaisri, K., \& Cheng, R. (2010). Exploring the relationship between corporate, internal and employer branding. Journal of Product and Brand Management, 19(6), 401409. doi:10.1108/10610421011085712

Fournier, S. (1998). Consumers and their brands: Developing relationship theory in consumer research. Journal of Consumer Research, 24(4), 343-353. doi:10.1086/209515

French, A., \& Smith, G. (2010). Measuring political brand equity: A consumer oriented approach. European Journal of Marketing, 44(3/4), 460-477. doi:10.1108/ 03090561011020534

Gillham, B. (2005). Research interviewing: The range of techniques. Maidenhead: Open University Press.

Gordon, W. (1999). Assessing the brand through research. In D. Cowley (Ed.), Understanding brands. London: Kogan Page.

Graziano, A. M., \& Raulin, M. L. (2007). Research methods: A process of inquiry. Boston: Pearson.

Guzman, F., \& Sierra, V. (2009). A political candidate's brand image scale: Are political candidates brands? Journal of Brand Management, 17(3), 207-217. doi:10.1057/ bm.2009.19

Harris, F., \& de Chernatony, L. (2001). Corporate branding and corporate brand performance. European Journal of Marketing, 35(3/4), 441-456. doi:10.1108/03090560110382101

Harris, P., \& Lock, A. (2010). Mind the gap: The rise of political marketing and a perspective on its future agenda. European Journal of Marketing, 44(3/4), 297-307. doi:10.1108/ 03090561011020435

Heffernan, R. (2001). New labour and Thatcherism: Political change in Britain. Basingstoke: Palgrave.

Helm, T. (2010, January 3). Cameron to pledge NHS cash boost for poorest. The Observer, pp. 1-8.

Hickson, K. (2005). The political thought of the Conservative Party since 1945. Basingstoke: Palgrave.

Joachimsthaler, E., \& Aaker, D. A. (1997). Building strong brands without mass media. Harvard Business Review, 75(1), 39-50. Retrieved from http://web.b.ebscohost.com/ehost/ pdfviewer/pdfviewer?vid=4\&sid =ad156bc0-e26f-4f53-854a-6cf5c6dfa809\%40sessionmg r115\&hid = 114

Kapferer, J. (2001). Strategic brand management. London: Kogan Page.

Kapferer, J. N. (2008). The new strategic brand management: Creating and sustaining brand equity long term. London: Kogan Page.

Kavanagh, D. (2000). British politics: Continuities and change. Oxford: Oxford University Press.

Keller, K. L. (1999). Managing brands for the long run: Brand reinforcement and revitalization strategies. California Management Review, 41(3), 102-124. Retrieved from http://web.b. 
ebscohost.com/ehost/pdfviewer/pdfviewer?vid=3\&sid=fd28d0e0-73b6-4c65-9613-b4e8a c0629c6\%40sessionmgr114\&hid $=114$

Kvale, S. (1996). An introduction to qualitative research interviewing. London: Sage.

Lane, R. (1972). Political man. New York, NY: Free Press.

Lee, S., \& Beech, M. (2009). The conservatives under David Cameron: Built to last? Hampshire: Palgrave Macmillan.

Lees-Marshment, J. (2009). Political marketing: Principles and applications. Abingdon: Routledge.

Lilleker, D. G. (2005). Political marketing: The cause of an emerging democratic deficit in Britain? Journal of Nonprofit and Public Sector Marketing, 14(1-2), 5-26. doi:10.1300/ J054v14n01_02

Lilleker, D. G., Jackson, N. A., \& Scullion, R. (2006). The marketing of political parties: Political marketing at the 2005 British General Election. Manchester: Manchester University Press.

Lloyd, J. (2006). The 2005 general election and the emergence of the negative brand. In D. G. Lilleker, N. A. Jackson, \& R. Scullion (Eds.), The marketing of political parties: Political marketing at the 2005 British General Election (pp. 59-80). Manchester: Manchester University Press.

Lock, A., \& Harris, P. (1996). Political marketing -Vive la différence! European Journal of Marketing, 30(10/11), 14-24. doi:10.1108/03090569610149764

Malhotra, N. K., \& Birks, D. F. (2003). Marketing research: An applied approach. Essex: Pearson.

Mauser, G. A. (1983). Political marketing: An approach to campaign strategy. New York, NY: Praeger.

McCracken, G. (1988). The long interview. London: Sage.

Moufahim, M., \& Lim, M. (2009). Towards a critical political marketing agenda? Journal of Marketing Management, 25(7/8), 763-776.

Nandan, S. (2005). An exploration of the brand identity-brand image linkage: A communications perspective. Journal of Brand Management, 12(4), 264-278. doi: $10.1057 /$ palgrave.bm. 2540222

Needham, C. (2006). Special issue papers brands and political loyalty. Journal of Brand Management, 13(3), 178-187. doi:10.1057/palgrave.bm.2540260

Nilson, T. H., \& Surrey, N. C. L. (1998). Competitive branding: Winning in the market place with value-added brand. Chichester: Wiley.

Norton, P. (1996). The conservative party. Hertfordshire: Prentice Hall/Harvester Wheatsheaf.

Ormrod, R. P. (2011). Limitations and implications of product-oriented, sales-oriented and market-oriented political parties: Evidence for public affairs. Journal of Public Affairs, 11(4), 395-405. doi:10.1002/pa.428

O'Shaughnessy, N. J., \& Henneberg, S. C. (2007). The selling of the President 2004: A marketing perspective. Journal of Public Affairs, 7, 249-268.

Osuagwu, L. (2008). Political marketing: conceptualisation, dimensions and research agenda. Marketing Intelligence and Planning, 26(7), 793-810.

Panwar, J. S. (2004). Beyond consumer marketing: Sectional marketing and emerging trends. London: Sage.

Peng, N., \& Hackley, C. (2007). Political marketing communications planning in the UK and Taiwan: Comparing insights from leading practitioners. Marketing Intelligence and Planning, 25(5), 483-498. doi:10.1108/02634500710774950

Pich, C., Dean, D., \& Punjaisri, K. (2014). Political brand identity: An examination of the complexities of conservative brand and internal market engagement during the $2010 \mathrm{UK}$ General Election campaign. Journal of Marketing Communications. doi:10.1080/ 13527266.2013.864321

Ponnam, A. (2007). Comprehending the strategic brand building framework of Kingfisher in the context of the brand identity prism. The IUP Journal of Brand Management, 4(4), 63-73. 
Retrieved from http://web.b.ebscohost.com/ehost/pdfviewer/pdfviewer? vid=3\&sid=66b631b1eae4-467e-b218d1fbc6aa91d6\%40sessionmgr198\&hid=114

Rawson, E. A. G. (2007). Perceptions of the United States of America: Exploring the political brand of a nation. Place Branding and Public Diplomacy, 3(3), 213-221. doi:10.1057/ palgrave.pb.6000067

Reeves, P., de Chernatony, L., \& Carrigan, M. (2006). Building a political brand: Ideology or voter-driven strategy. Journal of Brand Management, 13(6), 418-428. doi:10.1057/ palgrave.bm.2540283

Robinson, J. (2004). Repackaging our politicians: Marketing MPs in an MMP world. New Zealand Marketing Magazine, 23(5), 12-19. Retrieved from http://nz.vlex.com/vid/ branding-repackaging-politicians-mmp-67487830

Ross, J., \& Harradine, R. (2011). Fashion value brands: The relationship between identity and image. Journal of Fashion Marketing and Management: An International Journal, 15(3), 306-325. doi:10.1108/13612021111151914

Rubin, H. J., \& Rubin, I. S. (1995). Qualitative interviewing: The art of hearing data. London: Sage.

Saaksjarvi, M., \& Samiee, S. (2011). Relationships among brand identity, brand image and brand preference: Differences between cyber and extension and retail brands over time. Journal of Interactive Marketing, 25, 169-177. doi:10.1016/j.intmar.2011.04.002

Sabatini, C. A. (2002). Whom do international donors support in the name of civil society. Development in Practice, 12(1), 7-19.

Schneider, H. (2004). Branding in politics - Manifestations, relevance and identity-oriented management. Journal of Political Marketing, 3(3), 41-67. doi:10.1300/J199v03n03_03

Schutt, R. K. (2004). Investigating the social world: The process and practice of research. London: Sage.

Smith, D. (2009a, December 20). The party's truly over. The Sunday Times Magazine, pp. 7071.

Smith, G. (2005). Positioning political parties: The 2005 UK General Election. Journal of Marketing Management, 21, 1135-1149. doi:10.1362/026725705775194184

Smith, G. (2009b). Conceptualizing and testing brand personality in British politics. Journal of Political Marketing, 8(3), 209-232. doi:10.1080/15377850903044858

Smith, G., \& French, A. (2009). The political brand: A consumer perspective. Marketing Theory, 9(2), 209-226. doi:10.1177/1470593109103068

Smith, G., \& Speed, R. (2011). Cultural branding and political marketing: An exploratory analysis. Journal of Marketing Management, 27(13-14), 1304-1321. doi:10.1080/ 0267257X.2011.628449

Srivastava, R. K. (2011). Understanding brand identity confusion. Marketing Intelligence and Planning, 29(4), 340-352. doi:10.1108/02634501111138527

Van Gelder, S. (2005). Global brand strategy: Unlocking branding potential across countries, cultures and markets. London: Kogan Page.

Viot, C. (2011). Can brand identity predict brand extensions' success or failure? Journal of Product and Brand Management, 20(3), 216-227. doi:10.1108/10610421111134941

Warren, C. A. B., \& Karner, T. X. (2005). Discovering qualitative methods: Field research, interviews and analysis. Los Angeles, CA: Roxbury.

Wong, J. (2010). Using a brand identity index for relevancy in teaching collegiate marketing. Journal of Applied Business and Economics, 10(5), 52-60.

Zikmund, W. G. (2003). Business research methods. Mason, OH: Thomson Learning SouthWestern. 


\section{Appendix A. Interview guide: internal stakeholders}

\section{Opening - introduction}

- Research outline - confidentiality - audio tape

\section{Biographical information}

- How long in politics - how - background - university - other roles/jobs Conservative supporter

\section{Conservative Party - envisaged}

- Current identity

- Envisaged identity

- Values

- Who for

- Compare/differ

- More personality than ideology

- Clear united direction

- Resonating

- Young citizens

- Regional/Central Conservative Party values

- Distinction between Tory and Conservative

\section{History}

- Helped/hindered

- Old perceptions - Nasty Party

\section{Class}

- How - modifications/adaptations

\section{David Cameron}

- Attempted to change Party

- Influenced

- Internal relations

- Divided

- Made a difference

- Other Conservative leaders

- Cameron's Conservatives 


\section{Personal perceptions}

- How would you describe what it means to be a Conservative

- Feelings

- Changed

- Similar values

- Perceptions

- Citizens see the party

- Replacement of old logo

- United

- Relationships with other members

- Europe - change - society

- Social responsibility

- Personal beliefs/different

\section{Personal perceptions - David Cameron}

- Changed

- Support/dislike

- Further change

- Desires

- Adaptations

\section{Closure}

- Questions for me

- Summarise findings

- Ethical procedures

- Contact information

\section{Appendix B. Internal stakeholders}

Table B.1 Outline of sample for phase 1 - internal Conservative stakeholders.

\begin{tabular}{lcl}
\hline Code & Element of the Conservative Party & Date interviewed \\
\hline P1 & Professional Party & 15 December 2009 \\
P2 & Professional Party & 18 December 2009 \\
P3 & Professional Party & 19 December 2009 \\
P4 & Professional Party & 19 December 2009 \\
P5 & Voluntary Party & 19 December 2009 \\
P6 & Parliamentary Party & 6 January 2010 \\
P7 & Professional Party & 10 January 2010 \\
\hline
\end{tabular}


Table B.1 (Continued).

\begin{tabular}{lll}
\hline Code & Element of the Conservative Party & Date interviewed \\
\hline P8 & Professional Party & 10 January 2010 \\
P9 & Professional Party & 10 January 2010 \\
P10 & Parliamentary Party & 10 January 2010 \\
P11 & Parliamentary Party & 11 January 2010 \\
P12 & Parliamentary Party & 11 January 2010 \\
P13 & Voluntary Party & 11 January 2010 \\
P14 & Parliamentary Party & 12 January 2010 \\
P15 & Professional Party & 12 January 2010 \\
P16 & Parliamentary Party & 23 January 2010 \\
P17 & Parliamentary Party & 3 February 2010 \\
P18 & Parliamentary Party & 3 February 2010 \\
P19 & Parliamentary Party & 3 February 2010 \\
P20 & Parliamentary Party & 4 February 2010 \\
P21 & Parliamentary Party & 4 February 2010 \\
P22 & Voluntary Party & 11 February 2010 \\
P23 & Professional Party & 17 February 2010 \\
P24 & Parliamentary Party & 17 February 2010 \\
P25 & Voluntary Party & 17 February 2010 \\
P26 & Parliamentary Party & 1 March 2010 \\
P27 & Parliamentary Party & 1 March 2010 \\
P28 & Voluntary Party & 2 March 2010 \\
P29 & Voluntary Party & 2 March 2010 \\
P30 & Professional Party & 10 March 2010 \\
\hline & &
\end{tabular}

\section{About the authors}

Christopher Pich is a lecturer in marketing at Nottingham Business School, Nottingham Trent University. He has recently completed his $\mathrm{PhD}$ research into political branding of the UK Conservative Party and the application of marketing theory to the political environment. Christopher is an active researcher currently focusing on new political brands and research on qualitative projective techniques in political marketing.

Corresponding author: Christopher Pich, Nottingham Trent University, Nottingham Business School, Marketing Division, 6th Floor Newton Building, Burton Street Nottingham, NG1 4BU, UK.

\section{T 01158483862}

EChristopher.pich@ntu.ac.uk

Dianne Dean is a senior lecturer in marketing at the Hull University Business School. She has written several papers on political marketing, as well as working on other specialist areas such as contemporary family decision making and consumer studies of electronic in-home retailing. Prior to coming into academic life she worked for a number of years in a marketing consultancy, having started her marketing career in the pharmaceutical industry. She graduated from the University of Hull with a degree in politics and completed her doctorate at the University of Stirling. 